
\title{
DENTAL TREATMENT OF A PATIENT WITH TREACHER COLLINS
SYNDROME UNDER GENERAL ANAESTHESIA: A CASE REPORT
}

\begin{abstract}
This article reports a case of Treacher Collins syndrome (TCS) in a five-year-old male patient treated in Kırıkkale University, Department of Pediatric Dentistry. We defined the clinic signs and symptoms of the case and suggested a treatment plan. Treatment procedures for malformations caused by the syndrome should be planned and performed specifically for the patient. In our patient with low treatment compliance, dental examination, filling and partial prosthesis treatment was successfully applied under general anesthesia.
\end{abstract}

Keywords: Treacher Collins Syndrome, pediatric dentistry, general anaesthesia
*Aslı Soğukpınar ${ }^{1}$

(iD) Merve Erkmen Almaz ${ }^{2}$

ORCID IDs of the authors:

0000-0002-1934-9945

0000-0001-6766-2023

${ }^{1}$ Fatma Kemal Timuçin Oral and Dental Health Hospital, Adana, Turkey

${ }^{2}$ Department of Pediatric Dentistry, Faculty of

Dentistry, Kırıkkale University, Kırıkkale, Turkey.

Received : $: 27.10 .2018$

Accepted $\quad: 16.01 .2019$

How to Cite: Soğukpınar A, Almaz ME. Dental Treatment of a Patient with Treacher Collins Syndrome Under General Anaesthesia: A Case Report. Cumhuriyet Dent J 2019;22:1:136-139. 


\section{INTRODUCTION}

Treacher Collins syndrome (TCS) is an autosomal dominant disorder of craniofacial development and also called as mandibulofacial dysostosis The incidence of the syndrome is approximately 1:10,000 to1:50,000 livebirths. ${ }^{2}$ The clinical features are formed as a result of loss of function and mutation of the TCOF1 gene located on chromosome $5 \mathrm{q} 32 .{ }^{1}$

A patient with TCS syndrome presents with a peculiar, nearly pathognomonic face with ear malformations, downward slanting palpebral fissures, lower eyelid coloboma and partial absence of lower eyelashes. Patients with TCS may develop dental abnormalities such as missing teeth (tooth agenesis), discoloration of the teeth (enamel opacities), widely-spaced teeth, abnormal eruption of permanent teeth (ectopic eruption of maxillary first molars), malocclusion (improper positioning of the teeth and jaw). ${ }^{2}$ Also heart, kidneys, vertebral column and extremities may be affected by the syndrome. ${ }^{3}$ TCS is known to be associated with upper airway obstruction and difficult intubation during airway management for anesthesia because of mandibular micrognatia, small oral apertura and temporomandibular joint abnormality. ${ }^{2}$

The aim of this case report was to present a pediatric patient with Treacher Collins Syndrome (TCS) who underwent dental care under general anesthesia (GA).

\section{CLINICAL CASE REPORT}

A 5-year-old male patient, who was diagnosed as TCS, referred to Department of Pediatric Dentistry of Kırıkkale University with a complaint of dental pain. Clinically he had malar hypoplasia, external ear abnormalities, colobama, partial absence of lower eyelashes and lower lid with absent cilia and zygomatic arch hypoplasia (Table 1 and Figure 1). Intraoral examination revealed caries on primary insicors and molars on his upper and lower jaws $(55,53,63,65,74,75,84,85)$ and upper primary anterior and molar teeth were found to be missing $(54,52,51,61,62,64)$.
Table 1. The main clinical orofacial findings of $\mathrm{TCS}^{12}$

\begin{tabular}{|l|c|}
\hline \multicolumn{1}{|c|}{ Clinical findings } & $\begin{array}{c}\text { Findings of our } \\
\text { patient } \\
(+/-)\end{array}$ \\
\hline Mandibular hypoplasia & + \\
\hline Colobama & + \\
\hline $\begin{array}{l}\text { Total or partial absence of lower } \\
\text { eyelashes }\end{array}$ & + \\
\hline External ear malformations & + \\
\hline Hearing loss & + \\
\hline Cleft palate & + \\
\hline Shortened soft palate & - \\
\hline Malocclusion & - \\
\hline Anterior open bite & + \\
\hline Enamel hypoplosia & + \\
\hline Palpebral fissures & + \\
\hline Zygomatic arch hypoplasia & + \\
\hline Retrusive mandible & + \\
\hline Missing teeth & + \\
\hline Widely-spaced teeth & + \\
\hline Abnormal eruption of certain teeth & + \\
\hline Nasal deformity & + \\
\hline & + \\
\hline
\end{tabular}

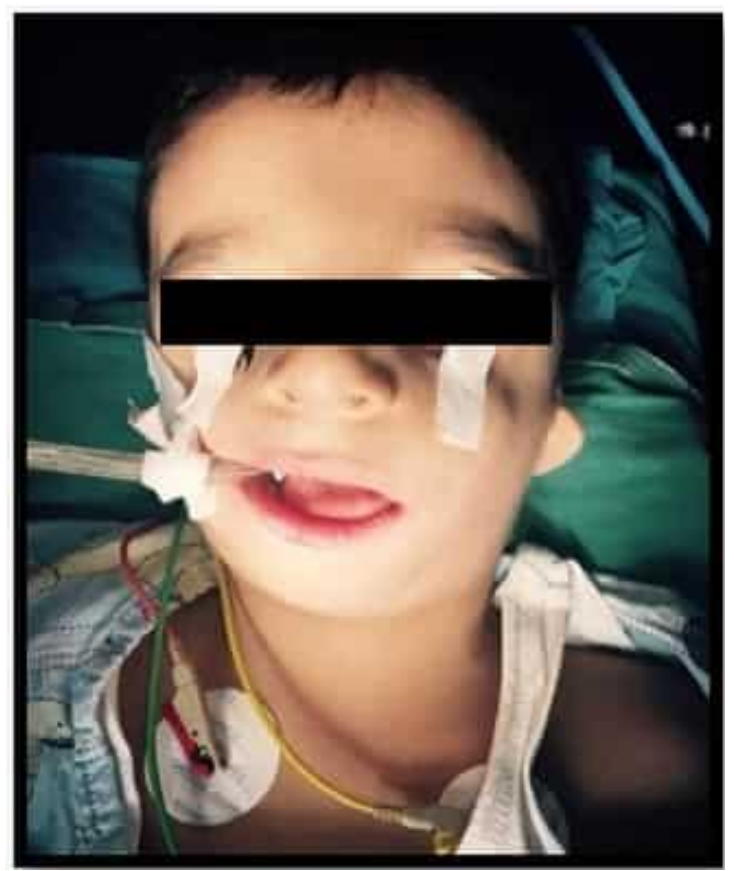

Figure 1. Frontal view under general anesthesia

The patient had prior examination and treatment under GA and teeth \#54, 52, 51, 61, 62, 64 were extracted (Figure 2A and 2B). The comprehensive treatment for the patient was planned as fillings for decayed teeth and a pediatric partial denture, but the patient did not comply with the dental treatment. Radiological examination such as panoramic film, lateral cephalometry or computed 
tomography can not be performed because of the cooperation problem. We discussed the importance of the dental treatment with the parents and decided to treat the patient under GA after obtaining consent from parents.
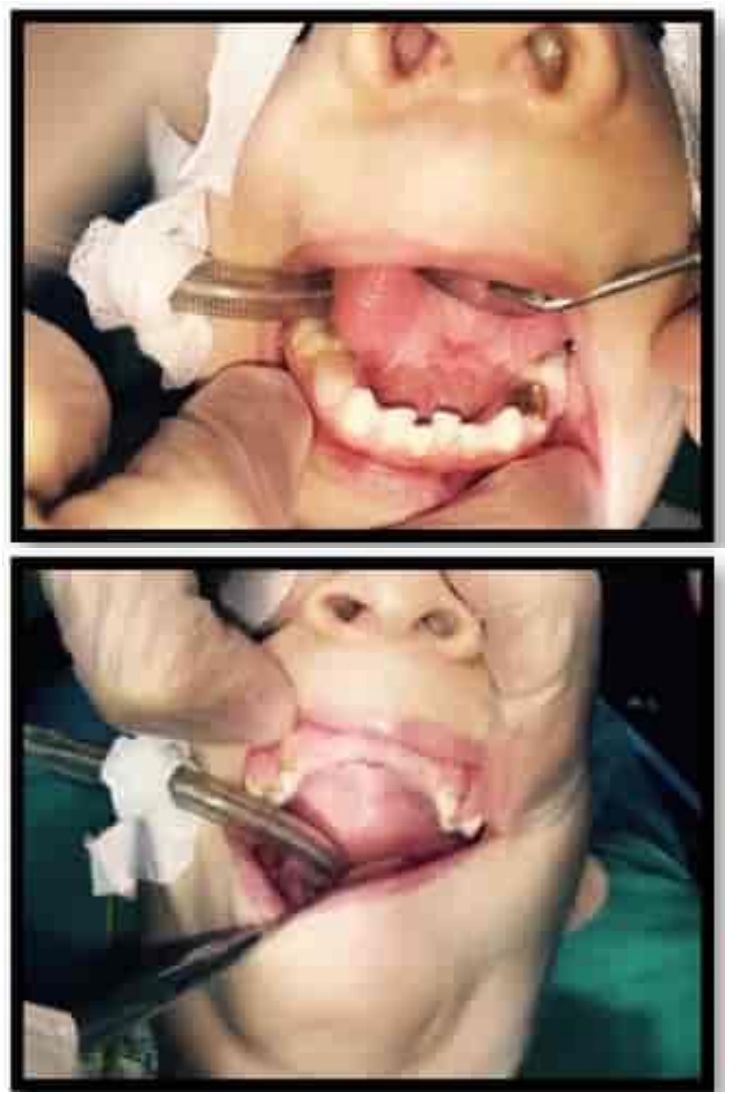

Figure 2A and 2B. Intraoral view of the upper and lower jaw before the operation

He had comprehensive dental care under GA. In the process of GA, despite the use of a fiber-optic airway instrument, intubation was extremely difficult due to the small mandible and its retroposition. All teeth were restored using self-etch bonding agent (3M Adeziv 200T, St. Paul, MN, USA) and compomer (DyractExtra A2, Dentsply, Konstanz, Germany). Following restorations, maxillary impression was taken using alginate (BluePrint X-creme, Dentsply International). Then topical fluoride therapy was applied using fluor varnish (Sultan, USA).

Acrylic denture teeth (TriadTruTray, Dentsply International) were used for proper lip support and proper plane of occlusion in the partial denture (Figure 3). The GA procedures as entubation, administration of anesthetic drugs and post-operative complications were managed with high-risk patient profile.

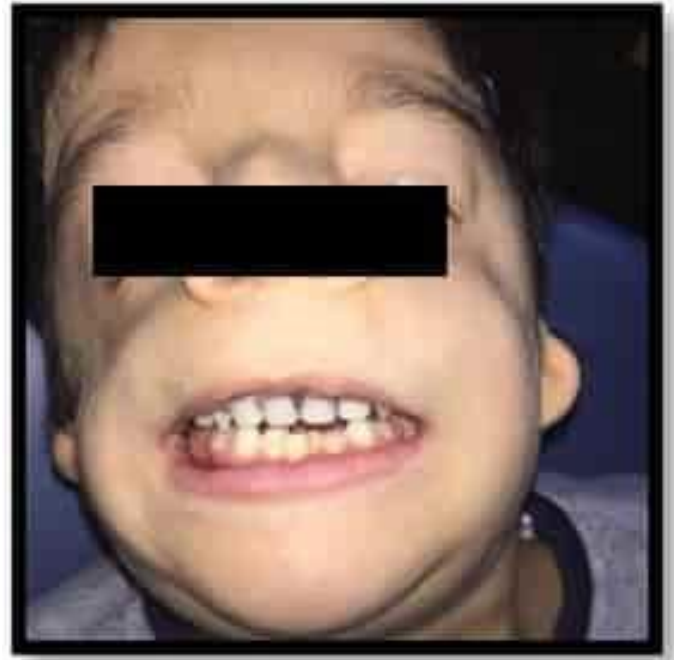

Figure 3. Frontal view of the partial denture

\section{DISCUSSION}

TCS is a genetic disorder affecting the whole facial region like eye bones, zygomas, maxillary and mandible, chin and ears which may be absent or malformed. ${ }^{2}$ These organs all originate from the neural crest. ${ }^{4}$

Treacher Collins syndrome is usually diagnosed at birth by radiological data and molecular tests. Also molecular analysis (amniocentesis and chorionic villous sampling) can be performed prenatally. ${ }^{5}$ Polyhydramnios, abnormal fetal swallowing, microcephaly, distorted facial characteristics like antimongoloid slanting palpebral fissures, malformation of the auricles, microgranthia can be shown by ultrasound. ${ }^{6-8}$ The history of our patient revealed that the diagnosis of TCS was performed with the help of detailed clinical evaluation and molecular genetic tests. While $40 \%$ of the patients have genetic mutation, more than $60 \%$ of TCS cases have no family history. ${ }^{9}{ }^{10}$ In this case the patient had no family history of TCS. Although the high incidence of obstructive sleep apnea (OSA) can be noticed in TCS patients; ${ }^{11}$ in our case there is no OSA syndrome diagnosis according to the anamnesis taken from the parents. The case was clinically defined as TCS depending on the typical extra oral symptoms. ${ }^{2}$ The patient had malar hypoplasia, external ear abnormalities, antimongoloid slant of the eyes and lower lid with absent cilia.

Our patient had dental pain because of caries. The conventional treatment can not be performed because of the patient's uncompliance; so the patient was treated under GA. Before the general 
anesthesia protocol for pediatric patients ${ }^{12}$, he had been sedated with intravenous midazolam because of uncooperative behaviour.

In the literature, TCS's signs of mandibular micrognathia and limitation of mouth opening was associated with difficult intubation under general anaesthesia. ${ }^{2}$ Boku et al. ${ }^{13}$ noticed that because of limitation of mouth opening, laryngeal mask airway and Glide Scope was not preferred; so fiberoptic tracheal intubation was used. In our case, due to the patient's mandibular hypoplasia and limitation of mouth opening, mask ventilation was carefully performed. While the patient is awakening from anesthesia, dyspnea and cyanosis were observed; it may be associated with restrictive airway pathology. Under general anaesthesia, dental treatment was quite successful. The patient's partial prosthesis was compatible with maxillary arch and after six months from the operation, his family noticed that he was using the partial prosthesis successfully. The patient is currently under regular follow-up.

\section{CONCLUSIONS}

Treacher Collins syndrome is a complex situation of mandibulofacial dysplasia, which requires a multidisciplinary management from birth to adulthood. Dental abnormalities need complex treatment modalities. With the impetidive features of the syndrome which make the procedures complicated, comprehensive treatment should be planned and performed with a multidiciplinary approach including general anesthesia.

\section{ACKNOWLEDGEMENTS}

None

\section{CONFLICTS OF INTEREST}

None

\section{Genel Anestezi Altında Treacher Collins Sendromlu Bir Hastanın Diş Tedavisi: Vaka Raporu}

\section{$\ddot{O} Z$}

Bu vakada Kırıkkale Üniversitesi Çocuk Diş Hekimliği Bölümü'nde tedavi edilen Treacher Collins Sendromlu 5 yaşındaki erkek hasta sunulmaktadır. Vakanın klinik semptom ve bulguları tanımlanmıs ve tedavi planlaması yapılmıştır. Sendromun sebep olduğu malformasyonlar nedenli tedavi prosedürleri hastaya özel olarak planlanmal ve uygulanmalıdır. Tedavi uyumu düşük olan hastamizda genel anestezi altında dental muayene ve dolgu ve parsiyel protez tedavisi başarll bir şekilde uygulanmistır. Anahtar kelimeler: Treacher Collins sendromu, çocuk diş hekimliği, genel anestezi.

\section{REFERENCES}

1.Dixon MJ. Treacher Collins syndrome. J Med Genet 1995;32:806.

2. National Organization for Rare Disorders. Treacher Collins Syndrome. 2012. https://rarediseases.org/rarediseases/treacher-collins-syndrome

3. Magalhães $\mathrm{MH}$, da Silveira $\mathrm{CB}$, Moreira CR, Cavalcanti MGP. Clinical and imaging correlations of Treacher Collins syndrome: report of two cases. Oral Surg, Oral Med, Oral Pathol, Oral Radiol, Endod 2007;103:836-842.

4. Chandra S. Textbook of Dental and oral histology with embryology. Jaypee Brothers Medical Publishers Ltd. 2007.

5. van Gijn DR, Tucker AS, Cobourne MT. Craniofacial development: current concepts in the molecular basis of Treacher Collins syndrome. Br J Oral Maxillofac Surg 2013;51:384-388.

6. Merz E, Weber G, Bahlmann F, Miric-Tesanic D. Application of transvaginal and abdominal threedimensional ultrasound for the detection or exclusion of malformations of the fetal face. Ultrasound Obstet Gynecol 1997;9:237-243.

7. Rotten D, Levaillant J, Martinez H, Ducou le Pointe H, Vicaut É. The fetal mandible: a $2 \mathrm{D}$ and $3 \mathrm{D}$ sonographic approach to the diagnosis of retrognathia and micrognathia. Ultrasound Obstet Gynecol 2002;19:122-130.

8. Tanaka Y, Kanenishi K, Tanaka H, Yanagihara T, Hata T. Antenatal three-dimensional sonographic features of Treacher Collins syndrome. Ultrasound Obstet Gynecol 2002;19:414-415.

9. Dauwerse JG, Dixon J, Seland S, Ruivenkamp CA, van Haeringen A, Hoefsloot LH, Peters DJ, Boers AC, Daumer-Haas C, Maiwald R, Zweier C, Kerr B, Cobo AM, Toral JF, Hoogeboom AJ, Lohmann DR, Hehr U, Dixon MJ, Breuning MH, Wieczorek D. Mutations in genes encoding subunits of RNA polymerases I and III cause Treacher Collins syndrome. Nat Genet 2011;43:20.

10. Conte C, D'Apice MR, Rinaldi F, Gambardella S, Sangiuolo F, Novelli G. Novel mutations of TCOF1 gene in European patients with Treacher Collins syndrome. BMC Med Genet 2011;12:125.

11. Chang CC, Steinbacher DM. Treacher collins syndrome. Semin Plast Surg 2012;26:83-90.

12. Crocker K, Black AE. Assessment and management of the predicted difficult airway in babies and children. Anaest Intensive Care Med 2009;10:200-205.

13. Boku A, Hanamoto $\mathrm{H}$, Kudo C, Morimoto $\mathrm{Y}$, Sugimura M, Tooyama M, Niwa H. Airway management for Treacher Collins syndrome with limited mouth opening. Open J Anesthesiol 2013;3:90-92. 